\title{
The effect of hypoxia on permeability and bacterial translocation in Caco-2 adult and I-407 fetal enterocyte cell culture models
}

Accepted: 10 December 2002/Published online: 6 May 2003

(C) Springer-Verlag 2003

\begin{abstract}
Hypoxia has been implicated in the breakdown of the intestinal epithelial barrier in animals, leading to bacterial translocation (BT); however, the mechanism of this hypoxic insult is unknown. To determine the effects of hypoxic injury in vitro on epithelial membrane integrity, transepithelial electrical resistance (TEER), mannitol permeability (Ma-Pm), and BT were measured in both an adult (Caco-2) and fetal (I-407) intestinal epithelial cell culture model. Caco-2 adult and I-407 fetal epithelial cell monolayers were treated with or without bacteria $\left(1 \times 10^{7}\right.$ Escherichia coli. $\mathrm{C}-25)$, and then incubated under either normoxic (5\% $\mathrm{CO}_{2}$ in room air) or hypoxic $\left(5 \% \mathrm{CO}_{2}\right.$ and $\left.95 \% \mathrm{~N}_{2}\right)$ conditions at $37^{\circ} \mathrm{C}$ for $6 \mathrm{~h}$. Hypoxia caused a $10 \%$ increase in Ma-Pm in the I-407 fetal cell model independent of the bacterial challenge. In contrast, a bacterial challenge in the Caco-2 adult model caused a $485 \%$ increase in Ma-Pm independent of hypoxia. Neither hypoxia, nor C-25 bacteria, for $6 \mathrm{~h}$ caused BT in either cell culture model. In the adult cell culture model, bacteria appear to mediate changes in epithelial barrier function, with hypoxia having no effect. On the other hand, hypoxia is the major factor in the loss of epithelial barrier function in fetal epithelium, but has no effect on adult epithelium. The data suggest that the breakdown of barrier function caused by a hypoxic insult is the primary stimulus for subsequent BT in neonates.
\end{abstract}

Keywords Hypoxia - Bacterial translocation Epithelial barrier integrity $\cdot$ Fetal $\cdot$ Neonatal

Y. Tazuke $\cdot$ R. A. Drongowski · D. H. Teitelbaum

A. G. Coran $(\bowtie)$

Section of Pediatric Surgery,

University of Michigan Medical School,

F3970 Mott Children's Hospital,

Ann Arbor, Michigan, 48109-0245, USA

E-mail: acoran@umich.edu

Fax: + 1-734-9369784

\section{Introduction}

Several clinical conditions associated with bacterial translocation are also associated with tissue hypoxia, and include increased concentrations of circulating endotoxin [1, 2, 3, 4], burn wounds $[5,6,7,8,9,10]$, intestinal obstruction [11, 12,13,14], hemorrhagic shock $[1,15,16,17,18,19,20]$, and mesenteric ischemia $[16,21]$. Hypoxia has been implicated in the breakdown of the intestinal epithelial barrier in animals, which can lead to bacterial translocation (BT). Neonates, with their immature immune systems [22], may be at greater risk for developing sepsis after such conditions as malrotation, necrotizing enterocolitis, or ileus [23]. It has also noted that the intestinal mucosal barrier of newborns may be incompletely developed at birth, and thus allows increased intestinal transport of foreign antigens into the circulation [24]. To determine the effects of hypoxic injury in vitro on epithelial barrier integrity, transepithelial electrical resistance (TEER), mannitol permeability (Ma-Pm), and BT were measured in both an adult (Caco-2) and fetal (I-407) intestinal epithelial cell culture model.

\section{Materials and methods}

Cell cultures

The human, adult, enterocyte Caco-2 cell line (no. HTB37) and human, fetal enterocyte I-407 cell line (no. CCL-6), were obtained from the American Type Culture Collection, (Manassas, Va.). Caco-2 and I-407 cell lines were grown and maintained in Dulbecco's modified Eagle's medium (DMEM; Fisher, Pittsburgh, Pa.) supplemented with $10 \%$ fetal bovine serum (Fisher, Pittsburgh, Pa.), 1\% non-essential amino acids (Gibco, Grand Island, N.Y.), penicillin $\mathrm{G}(100 \mathrm{U} / \mathrm{ml})$, and streptomycin $(100 \mathrm{~g} / \mathrm{ml}$; Fisher, Pittsburgh, $\mathrm{Pa}$.), in a $5 \% \mathrm{CO}_{2}$ atmosphere at $37^{\circ} \mathrm{C}$. The media for Caco- 2 cells also contained $1 \%$ sodium pyruvate (Fisher, Pittsburgh, Pa.). After reaching 60-70\% confluence, cells (passages 3-5) were harvested by trypsinization with trypsin-EDTA (Gibco, Grand Island, N.Y.), washed and resuspended in DMEM. The cells were seeded at a density of $1 \times 10^{5}$ cells per well in Transwell cell culture inserts (Costar, Cambridge, Mass.) with $0.33-\mathrm{cm}^{2}$-sized 
porous filters (pore size $0.3 \mu \mathrm{m}$ ) and coated with $1.0 \mathrm{mg} / \mathrm{ml}$ rat-tail type-I collagen (Sigma, St. Louis, Mo.) in a two-chamber cell culture system (Costar). Both cells were then grown for 14 days in media to allow them to reach confluence and fully differentiate. Media were changed every second day.

\section{Experimental models}

The epithelial integrity was tested by measuring transepithelial electrical resistance (TEER) and mannitol permeability (Ma-Pm). Briefly, Caco-2 and I-407 epithelial cell monolayers were incubated under either normoxic $\left(5 \% \mathrm{CO}_{2}\right.$ in room air) or hypoxic $\left(5 \% \mathrm{CO}_{2}\right.$ and $\left.95 \% \mathrm{~N}_{2}\right)$ conditions at $37^{\circ} \mathrm{C}$ for $6 \mathrm{~h}$ [25]. To test whether hypoxia or bacteria have a greater or lesser role in the loss of epithelial barrier breakdown, both cell monolayers were also treated with or without bacteria $\left(1 \times 10^{7}\right.$ Escherichia coli. C-25; courtesy H. Ford, Pittsburgh, Pa.) under either normoxic or hypoxic conditions at $37^{\circ} \mathrm{C}$ for $6 \mathrm{~h}$. Briefly, Escherichia coli (E. coli) C-25, a nonpathogenic, streptomycin-resistant strain originally isolated from human gut flora, was used in these studies. The E. coli C-25 were grown overnight in brain-heart infusion medium, washed three times with PBS and resuspended in PBS at a concentration of $1 \times 10^{7}$ colony forming units (CFU) per milliliter. The initial concentration of bacteria was determined spectrophotometrically at a wavelength of $650 \mathrm{~nm}$. Prior to addition of bacteria, the monolayers were washed three times with DMEM without antibiotic supplements. After 30-min stabilization under normoxic or hypoxic conditions, E. coli C-25 was inoculated by adding $100 \mu \mathrm{l}$ of DMEM containing $1 \times 10^{6} \mathrm{CFU}$ of bacteria into the apical media.

Transepithelial electrical resistance (TEER) was measured before and after $6 \mathrm{~h}$ incubation under normoxic or hypoxic condition, with or without bacterial challenge, using an epithelial volt ohmmeter (EVOM; World Precision Instruments, Sarasota, Fla.). The TEER values obtained in the absence of cells were used as background, and resistances were expressed as $\mathrm{ohm} \times$ centimeters squared $\left(\mathrm{ohm} \cdot \mathrm{cm}^{2}\right)$.

After $6 \mathrm{~h}$ incubation under normoxic or hypoxic condition, with or without bacterial challenge, the monolayers were washed by media and then ${ }^{3} \mathrm{H}$-mannitol (molecular formula weight 182.2) was administered into the apical chamber. After $2 \mathrm{~h}$ incubation with ${ }^{3} \mathrm{H}$-mannitol, the media in the basal chamber was collected and measurements of tritium were obtained via a scintillation counter. The data are expressed as the scintillation counts in the basal chamber / (the scintillation counts in basal chamber + the scintillation counts in apical chamber) $\times 100$.

Translocated bacteria were measured according to previously published methodology [26, 27], with minor modifications. Following an additional $6 \mathrm{~h}$ incubation under normoxic or hypoxic conditions, samples from the basal chambers were taken and the number of bacterial CFUs was determined by the pour-plate assay using MacConkey's agar. The magnitude of BT was expressed as $\log 10(\mathrm{CFU} / \mathrm{ml})$.

\section{Statistics}

Results are expressed at the mean \pm SD. Statistical analysis was performed using linear regression analysis and one-way analysis of variance, with $P<0.05$ considered significant.

\section{Results}

\section{Effect of hypoxia on TEER}

Regarding the effect of hypoxia on TEER (Fig. 1), hypoxia had no effect on TEER compared with normoxic controls in the adult Caco-2 cell model; however, in

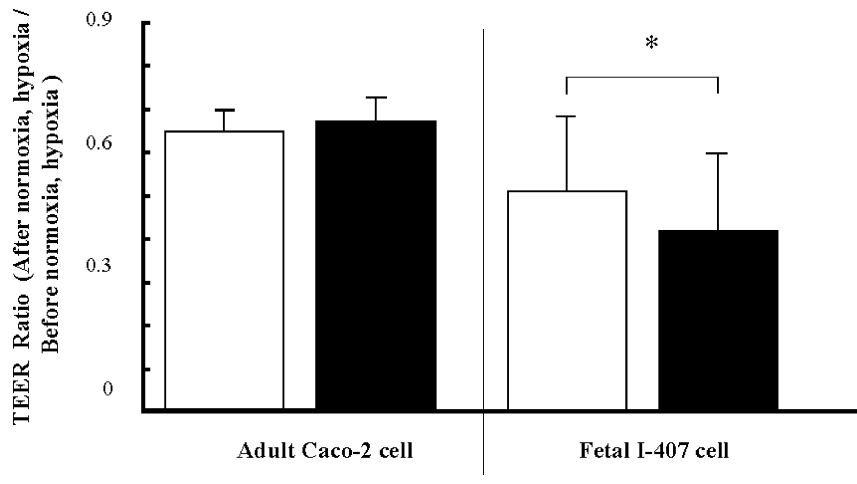

Fig. 1 The effect of hypoxia on transepithelial electrical resistance (TEER) in adult Caco-2 cell and fetal I-407cells. The results are expressed as the ratio of TEER before and after $6 \mathrm{~h}$ of normoxia or hypoxia. Open column normoxic models, solid column hypoxic models

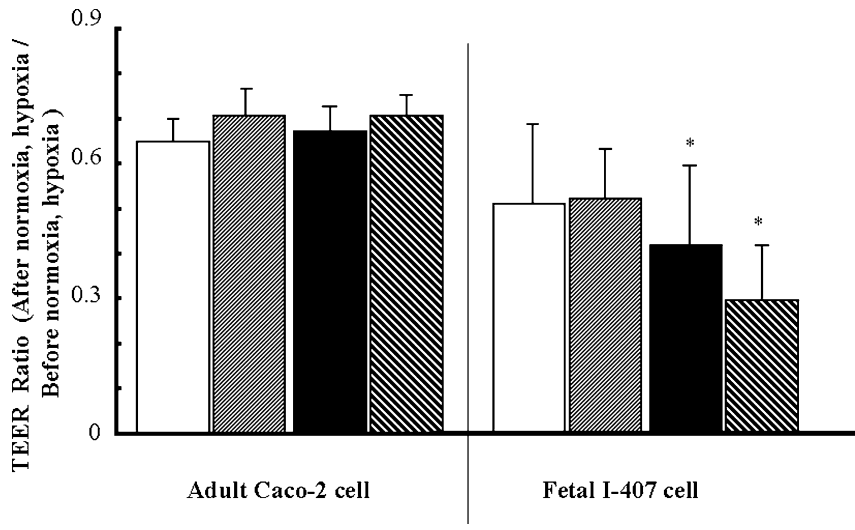

Fig. 2 The effect of bacteria on transepithelial electrical resistance (TEER) under normoxic/ hypoxic condition in adult Caco-2 cell and fetal I-407 cells. The results are expressed as the ratio of TEER before and after 6-hours of normoxia or hypoxia. Asterisk Significant difference between normoxia and hypoxia, $P<0.05$ in each cell line. Normoxic models without (open column) or with (shaded column) bacteria. Hypoxic models without (solid column) or with (hatched column) bacteria

the fetal I-407 cell model, hypoxia resulted in a significant decrease in TEER $(20 \%)$ compared with normoxia $(P<0.05)$.

\section{Effects of bacterial challenge on TEER}

Regarding the effects of bacterial challenge on TEER (Fig. 2), in both the adult and fetal cell lines, normoxia had no effect on TEER, and was used to assess a baseline condition of TEER. In the adult cell line, the addition of bacterial challenge, even under a hypoxic environment, had no effect on TEER. In contrast, in the fetal cell line hypoxia caused a significant decrease in TEER $(20 \% ; P<0.05$ vs control) which was further accentuated by a bacterial challenge $(43 \%$ decrease in TEER; $P<0.05)$. 
Effect of hypoxia on Ma-Pm

Regarding the effect of hypoxia on Ma-Pm (Fig. 3), under normoxic conditions Ma-Pm was found to be at a much higher level in the fetal I-407 cell culture model compared with adult Caco-2 cells. There was no change in mannitol permeability in the adult cell line with hypoxia. In contrast, mannitol permeability significantly increased with hypoxia by $17 \%(P<0.05)$ in the fetal cell line compared with controls.

\section{Effect of bacteria on Ma-Pm}

Regarding the effect of bacteria on Ma-Pm (Fig. 4), bacterial challenge in the Caco-2 adult model caused a

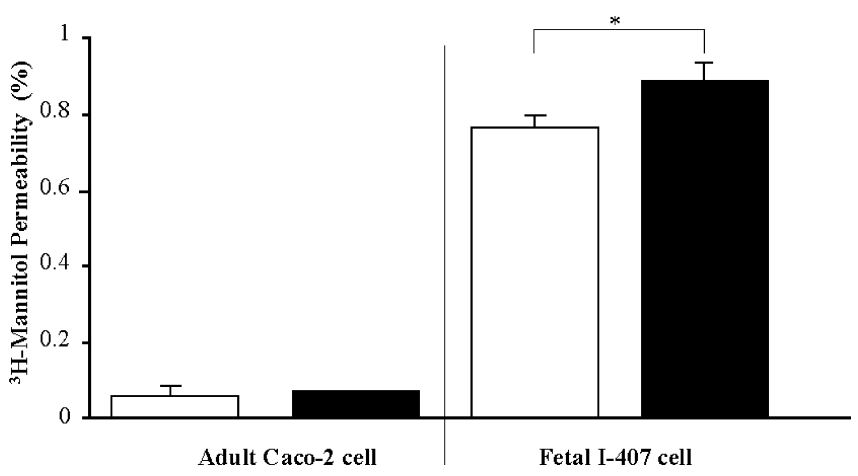

Fig. 3 The effect of hypoxia on mannitol permeability (Ma-Pm) in adult Caco-2 cells and fetal I-407 cells, measured by using the permeability of $3 \mathrm{H}$-mannitol. The data are expressed as the scintillation counts in the basal chamber / (the scintillation counts in basal chamber + the scintillation counts in apical chamber) $\times 100$. Asterisk Significant difference between normoxia and hypoxia, $P<0.05$ in each cell line. Open column normoxic models, solid column hypoxic models

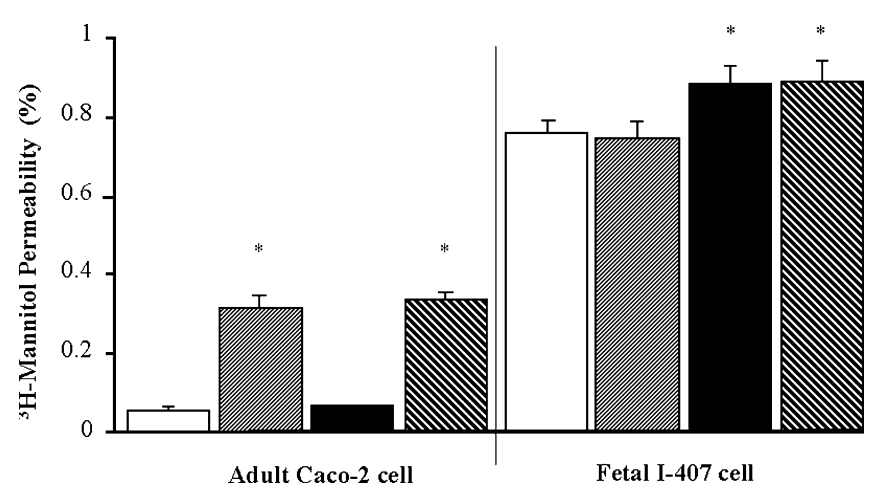

Fig. 4 The effect of bacteria on mannitol permeability (Ma-Pm) in adult Caco-2 and fetal I-407 cells under normoxic or hypoxic environments. The data are expressed the scintillation counts in the basal chamber / (the scintillation counts in basal chamber + the scintillation counts in apical chamber $\times 100$. Asterisk Significant difference between normoxia and hypoxia, $P<0.05$ in each cell line. Normoxic models without (open column) or with (shaded column) bacteria. Hypoxic models without (solid column) or with (hatched column) bacteria
$485 \%$ increase in Ma-Pm, which was independent of hypoxia. In contrast to the adult Caco- 2 model, bacterial challenge in the normoxic environment in the fetal I407 cells had no effect. In addition, bacterial challenge in a hypoxic environment did not increase mannitol permeability in the fetal I-407 cells; however, hypoxia caused a $10 \%$ increase in mannitol permeability in the fetal I-407 cells, which was independent of bacterial challenge $(P<0.05)$.

\section{Bacterial translocation}

After $6 \mathrm{~h}$ of either normoxia or hypoxia, bacteria C-25 was still detectable at a concentration of $1 \times 10^{5-6} \mathrm{CFU}$ in the apical media. No differences were observed between adults and fetal epithelial cell culture models; however, neither hypoxia, nor bacterial challenge, for $6 \mathrm{~h}$ resulted in BT from the apical chamber to the basal chamber in either cell culture model, despite the observed decrease in TEER and increase in Ma-Pm.

\section{Discussion}

Ischemic injury of the intestine is observed in several clinical settings among which are acute occlusive or low-flow states $[10,28,29]$ found in congenital intestinal malrotation with volvulus or secondary intestinal obstruction by ileus, tumor in adults or in trauma patients with hypovolemic, and hemorrhagic shock. Ischemic injury is complicated by re-perfusion injury via superoxide radicals [30,31], or by bacterial translocation [21] and the subsequent development of sepsis and/or multi organ dysfunction [32, 33]. In neonates, hypoxia is one of the more common major stresses to which an infant is exposed. Clinically, ischemic injury in neonates results in more septic cases than in adults $[34,35]$.

To address the different physiologic effects of hypoxia on adult and fetal epithelial cell culture models, we assessed epithelial integrity by measuring TEER and Ma-Pm. Adult Caco-2 cells are transformed human colon carcinoma cells and are one of the most popular cell lines for studying epithelial integrity and transport $[27,36,37,38,39,40]$. Fetal I407 cells have been known to form an immature, undifferentiated enterocyte monolayer and are used for studying neonatal/fetal epithelial integrity [41]. In the fetal models, the mucosal mucin compostion and presence of IgA has been reported to have an important role in preventing of BT [41, 42, 43, 44]. Under hypoxic conditions, TEER was adversely affected in the fetal I-407 monolayer model. It has been shown that a 1-h period of hypoxia causes massive apoptotic damage in adult Caco-2 cells and HT-29 cells [45]; however, in our well-differentiated monolayer model, adult Caco-2 cells did not show any decline of TEER after $6 \mathrm{~h}$ of hypoxia. The results with TEER mimic those with Ma-Pm in these cell culture models. 
Hypoxia caused increased active transport and paracellular membrane permeability of mannitol in the fetal I-407 cells compared with the adult Caco-2 cells. During hypoxia some enteral nutrients regulate mucosal barrier function [25, 46]. Moreover, following hypoxia, neonatal feeding intolerance and the increased risk of necrotizing enterocolitis are preceded by intestinal mucosal injury, BT, and dysmotility [47, 48, 49]. Our experimental data are consistent with these latter clinical observations.

Interestingly, a bacteria challenge caused a $485 \%$ increase in permeability in the Caco- 2 adult model independent of hypoxia. The mechanism for this increase in permeability is unknown. It is most likely not due to proliferation of bacteria, as bacterial growth during hypoxia has been reported to reach a stationary

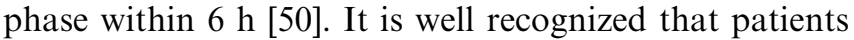
with bowel obstruction suffer from severe hypoxic intestinal injury and sepsis without vessel occlusion [1, 5, $6,7,8,9,10,11,12,13,14,15,16,17,18,19,20]$. Bacterial overgrowth in association with intestinal obstruction might have a greater effect on the intestinal epithelium of adults (vs neonates) during a hypoxic state. Furthermore, the extent of hypoxic injury might depend on a reperfusion injury followed by hypoxia, which may be influenced by chronic disease and aging factors. Again, these clinical observations are consistent with our experimental findings. Interestingly, the normoxic bacterial challenge had no effect in fetal I-407 cells on Ma-Pm; however, hypoxia caused a $10 \%$ increase in Ma-Pm in the I-407 fetal cell model independent of the bacterial challenge.

Although we anticipated that there would be BT after $6 \mathrm{~h}$ of incubation with bacteria, this was not the case. Neither hypoxia nor bacterial challenge for $6 \mathrm{~h}$ led to BT in either cell culture model. This lack of BT occurred despite the findings of a decreased TEER and increased Ma-Pm. This lack of BT was also seen in an acute hypoxia model in newborn rabbits previously published by us [51]. It is possible that with a longer period of hypoxia, or greater bacterial challenge, BT might have been observed. Nevertheless, despite the lack of BT in this study, significant changes in epithelial barrier function were observed. Such changes can lead to the passage of bacterial toxins (i.e., endotoxins) and foreign antigens into the host, both of which may be extremely deleterious.

\section{Conclusion}

In conclusion, we studied the effects of hypoxia and bacterial challenge on permeability and bacterial translocation in both Caco-2 adult and I-407 fetal enterocyte cell culture models. The observed differences between these two enterocyte cell lines may help to better understand the mechanisms involved in the loss of epithelial barrier function during various clinical settings associated with hypoxia.

\section{References}

1. Deitch EA, Bridges W, Baker J, Ma JW, Ma L, Grisham MB, Granger DN, Specian RD, Berg R (1988) Hemorrhagic shockinduced bacterial translocation is reduced by xanthine oxidase inhibition or inactivation. Surgery 104:191-198

2. Wells CL, Barton RG, Wavatne CS, Dunn DL, Cerra FB (1992) Intestinal bacterial flora, intestinal pathology, and lipopolysaccharide-induced translocation of intestinal bacteria. Circ Shock 37:117-123

3. Go LL, Healey PJ, Watkins SC, Simmons RL, Rowe MI (1995) The effect of endotoxin on intestinal mucosal permeability to bacteria in vitro. Arch Surg 130:53-58

4. Xu D, Qi L, Guillory D, Cruz N, Berg R, Deitch EA (1993) Mechanisms of endotoxin-induced intestinal injury in a hyperdynamic model of sepsis. J Trauma 34:676-682

5. Alexander JW (1990) Mechanism of immunologic suppression in burn injury. J Trauma 30:S70-S75

6. Alexander JW, Boyce ST, Babcock GF, Gianotti L, Peck MD, Dunn DL, Pyles T, Childress CP, Ash SK (1990) The process of microbial translocation. Ann Surg 212:496-511

7. Alexander JW, Gottschlich MM (1990) Nutritional immunomodulation in burn patients. Crit Care Med 18:S149-S153

8. Jones WG II, Minei JP, Barber AE, Fahey TJ, Shires GT III, Shires GT (1990) Additive effects of thermal injury and infection on the small bowel. Surgery 108:63-70

9. Jones WG II, Minei JP, Barber AE, Rayburn JL, Fahey TJ III, Shires GT III, Shires GT (1990) Bacterial translocation and intestinal atrophy after thermal injury and burn wound sepsis. Ann Surg 211:399-405

10. Deitch EA (1990) Intestinal permeability is increased in burn patients shortly after injury. Surgery 107:411-416

11. Deitch EA, Bridges WM, Ma JW, Ma L, Berg RD, Specian RD (1990) Obstructed intestine as a reservoir for systemic infection. Am J Surg 159:394-401

12. Deitch EA, Sittig K, Li M, Berg R, Specian RD (1990) Obstructive jaundice promotes bacterial translocation from the gut. Am J Surg 159:79-84

13. Deitch EA (1989) Simple intestinal obstruction causes bacterial translocation in man. Arch Surg 124:699-701

14. Samel S, Keese M, Kleczka M, Lanig S, Gretz N, Hafner M, Sturm J, Post S (2002) Microscopy of bacterial translocation during small bowel obstruction and ischemia in vivo-a new animal model. BMC Surg 2:6

15. Deitch EA, Bridges W, Berg R, Specian RD, Granger DN (1990) Hemorrhagic shock-induced bacterial translocation: the role of neutrophils and hydroxyl radicals. J Trauma 30:942-951

16. Morales J, Kibsey P, Thomas PD, Poznansky MJ, Hamilton SM (1992) The effects of ischemia and ischemiareperfusion on bacterial translocation, lipid peroxidation, and gut histology: studies on hemorrhagic shock in pigs. J Trauma 33:221-227

17. Koziol JM, Rush BF Jr, Smith SM, Machiedo GW (1988) Occurrence of bacteremia during and after hemorrhagic shock. J Trauma 28:10-16

18. Sori AJ, Rush BF Jr, Lysz TW, Smith S, Machiedo GW (1988) The gut as source of sepsis after hemorrhagic shock. Am J Surg 155:187-192

19. Koyluoglu G, Bakici MZ, Elagoz S, Arpacik M (2001) The effects of pentoxifylline treatment on bacterial translocation after hemorrhagic shock in rats. Clin Exp Med 1:61-66

20. Baker JW, Deitch EA, Li M, Berg RD, Specian RD (1988) Hemorrhagic shock induces bacterial translocation from the gut. J Trauma 28:896-906

21. Zhi-Yong S, Dong YL, Wang XH (1992) Bacterial translocation and multiple system organ failure in bowel ischemia and reperfusion. J Trauma 32:148-153

22. Israel EJ (1994) Neonatal necrotizing enterocolitis, a disease of the immature intestinal mucosal barrier. Acta Paediatr (Suppl) 396:27-32 
23. Caplan MS, Kelly A, Hsueh W (1992) Endotoxin and hypoxiainduced intestinal necrosis in rats: the role of platelet activating factor. Pediatr Res 31:428-434

24. Udall JN, Pang K, Fritze L, Kleinman R, Walker WA (1981) Development of gastrointestinal mucosal barrier. I. The effect of age on intestinal permeability to macromolecules. Pediatr Res 15:241-244

25. Kles KA, Turner JR, Tappenden KA (2002) 2001 Harry M. Vars Research Award. Enteral nutrients alter enterocyte function within an in vitro model similar to an acute in vivo rat model during hypoxia. J Parenter Enteral Nutr 26:71-76

26. Minami T, Tojo H, Shinomura Y, Matsuzawa Y, Okamoto M (1993) Purification and characterization of a phospholipase A2 from human ileal mucosa. Biochim Biophys Acta 1170:125-130

27. Hidalgo IJ, Raub TJ, Borchardt RT (1989) Characterization of the human colon carcinoma cell line (Caco-2) as a model system for intestinal epithelial permeability. Gastroenterology 96:736-749

28. Chiu CJ, Scott HJ, Gurd FN (1970) Intestinal mucosal lesion in low-flow states. II. The protective effect of intraluminal glucose as energy substrate. Arch Surg 101:484-488

29. Chiu CJ, McArdle AH, Brown R, Scott HJ, Gurd FN (1970) Intestinal mucosal lesion in low-flow states. I. A morphological, hemodynamic, and metabolic reappraisal. Arch Surg 101:478-483

30. Li C, Jackson RM (2002) Reactive species mechanisms of cellular hypoxia-reoxygenation injury. Am J Physiol Cell Physiol 282:C227-C241

31. Gebhardt BR, Ries J, Caspary WF, Boehles H, Stein J (1999) Superoxide: a major factor for stress protein induction in reoxygenation injury in the intestinal cell line Caco-2. Digestion $60: 238-245$

32. Antonsson JB, Fiddian-Green RG (1991) The role of the gut in shock and multiple system organ failure. Eur J Surg 157:3-12

33. Marshall JC, Christou NV, Horn R, Meakins JL (1988) The microbiology of multiple organ failure. The proximal gastrointestinal tract as an occult reservoir of pathogens. Arch Surg 123:309-315

34. Milner ME, Monte SM de la, Moore GW, Hutchins GM (1986) Risk factors for developing and dying from necrotizing enterocolitis. J Pediatr Gastroenterol Nutr 5:359-364

35. Kliegman RM, Walsh MC (1987) Neonatal necrotizing enterocolitis: pathogenesis, classification, and spectrum of illness. Curr Probl Pediatr 17:213-288

36. Fogh J, Fogh JM, Orfeo T (1977) One hundred and twentyseven cultured human tumor cell lines producing tumors in nude mice. J Natl Cancer Inst 59:221-226

37. Chantret I, Barbat A, Dussaulx E, Brattain MG, Zweibaum A (1988) Epithelial polarity, villin expression, and enterocytic differentiation of cultured human colon carcinoma cells: a survey of twenty cell lines. Cancer Res 48:1936-1942

38. Vachon PH, Beaulieu JF (1992) Transient mosaic patterns of morphological and functional differentiation in the Caco-2 cell line. Gastroenterology 103:414-423

39. Artursson P (1991) Cell cultures as models for drug absorption across the intestinal mucosa. Crit Rev Ther Drug Carrier Syst $8: 305-330$

40. Pinto M SR-LS, Appay MD, Kedinger M, Triadou N, Dussaulx E, Lacroix B, Simon-Assmann P, Haffen K, Fogh J, Zweibaum A (1983) Enterocyte-like differentiation and polarization of the human colon carcinoma cell line Caco-2 in culture. Biol Cell 47:323-330

41. Gork AS, Usui N, Ceriati E, Drongowski RA, Epstein MD, Coran AG, Harmon CM (1999) The effect of mucin on bacterial translocation in I-407 fetal and Caco-2 adult enterocyte cultured cell lines. Pediatr Surg Int 15:155-159

42. Okuyama H, Urao M, Lee D, Drongowski RA, Coran AG (1998) The effect of epidermal growth factor on bacterial translocation in newborn rabbits. J Pediatr Surg 33:225-228

43. Dickinson EC, Gorga JC, Garrett M, Tuncer R, Boyle P, Watkins SC, Alber SM, Parizhskaya M, Trucco M, Rowe MI, Ford HR (1998) Immunoglobulin A supplementation abrogates bacterial translocation and preserves the architecture of the intestinal epithelium. Surgery 124:284-290

44. Maxson RT, Johnson DD, Jackson RJ, Smith SD (1996) The protective role of enteral IgA supplementation in neonatal gutorigin sepsis. Ann N Y Acad Sci 778:405-407

45. Hinnebusch BF, Ma Q, Henderson JW, Siddique A, Archer SY, Hodin RA (2002) Enterocyte response to ischemia is dependent on differentiation state. J Gastrointest Surg 6:403-409

46. Tappenden KA (2002) Provision of phosphorylatable substrate during hypoxia decreases jejunal barrier function. Nutrition 18:168-172

47. Berseth CL, McCoy HH (1992) Birth asphyxia alters neonatal intestinal motility in term neonates. Pediatrics 90:669-673

48. Berg RD (1992) Bacterial translocation from the gastrointestinal tract. J Med 23:217-244

49. Berseth CL (1996) Gastrointestinal motility in the neonate. Clin Perinatol 23:179-190

50. Wells CL, VandeWesterlo EM, Jechorek RP, Erlandsen SL (1996) Effect of hypoxia on enterocyte endocytosis of enteric bacteria. Crit Care Med 24:985-991

51. Urao M, Coran AG, Drongowski RA, Teitelbaum DH (1996) Acute hypoxia does not increase bacterial translocation in newborn rabbits. J Pediatr Surg 31:665-669 